\title{
In 111 Satumomab Pendetide
}

National Cancer Institute

\section{Source}

National Cancer Institute. In 111 Satumomab Pendetide. NCI Thesaurus. Code C1469.

An radioimmunoconjug ate of the murine monoclonal antibody, Satumomab (MoAb

B72.3), conjug ated to the linker-chelator, glycyl-tyrosyl-(N,-

diethylenetriaminepentaacetic acid)-lysine hydrochloride (GYK-DTPA-HCl; pendetide)

labeled with indium 111 (In-111). Satumomab recognizes TAG-72, an antigen expressed

by the majority of adenocarcinomas. In-111 Satumomab pendetide emits gamma

radiation and X-Ray photons that can be captured by gamma camera allowing imaging of

TAG-72 expressing tissues. 